\title{
Failure of Trasylol to reduce intestinal content of trypsin and chymotrypsin in $\operatorname{man}^{1}$
}

\author{
D. M. GOLDBERG, R. CAMPBELL, AND A. D. ROY \\ From the University Department of Surgery and the Department of Biochemistry, Western Infirmary, \\ Glasgow
}

SUMMARY The daily output of trypsin and chymotrypsin was measured in the stools of four patients with an established ileostomy under controlled dietary and metabolic conditions for a control period of four days. Trasylol, given intravenously in a dose of 500,000 units over eight hours, failed to affect the output of enzymes over the next two days, or to alter the distribution of bound and soluble enzymes.

\begin{abstract}
About 10 years ago, a polypeptide obtained from beef parotid glands ('Trasylol', FBA Pharmaceuticals Ltd), was introduced for the treatment of acute pancreatitis. Its use was based upon its ability to inhibit pancreatic proteolytic enzymes and kinins said to be released during the course of the disease. Although some recent reports indicate that the drug may be of benefit (Hansson and Lenninger, 1967; Kneisel, 1968; Nodine and Greberman, 1968) these trials do not conform to double-blind criteria. Those that do are almost uniform in concluding that Trasylol is without proven effect in the treatment or prophylaxis of acute pancreatitis (Nardi, 1963; Skyring, Singer, and Tornya, 1965; Trapnell, Talbot, and Capper, 1967; Baden, Jordal, Lund, and Zachariae, 1967; Skinner, Corson, and Nardi, 1968; Howat, 1969). Bachrach and Schild (1968) found the drug statistically superior to a placebo but doubted its practical value. Although several reports indicate that the drug protects animals during experimental pancreatitis (McCutcheon and Race, 1963; Nemir, Hoferichter, and Drabkin, 1963; Kune,'1969), others have obtained disappointing results (Keynes, 1967; Dos Reis, 1967; Gabryelewicz, Niewiarowski, Prokopowicz, and Chlebowski, 1969).

The anti-trypsin effect of Trasylol has never Received for publication 12 December 1969.
\end{abstract}

${ }^{1}$ Please addiress requests for reprints to Dr D. M. Goldberg, Department of Chemical Pathology, Royal Hospital, Sheffield. been demonstrated in patients during acute pancreatitis, since raised levels of trypsin in the circulating body fluids do not often occur in untreated cases (Groisser, Rauch, Floch, and Bobruff, 1966) and normal serum contains antitrypsin activity ranging from $0.5 \mathrm{mg}$ to $3 \mathrm{mg} / \mathrm{ml}$ (Bundy and Mehl, 1958; Siegelman, Carlson, and Robertson, 1962; Kallos, Kahn, and Rizok, 1964). Two reports suggested to us an experimental model suitable for testing the anti-enzyme properties of Trasylol. Schultis and Rick (1964) described a reduction in the pancreatic enzyme response to secretin and pancreozymin in human subjects given Trasylol intravenously, and it has recently been stated that Trasylol raises the trypsin-inhibitor concentration of pancreatic juice (Morgan, Robinson, and White, 1968). We had developed techniques for quantitating the 24-hour output of pancreatic enzymes in human patients on ileal drainage (Roy, Campbell, and Goldberg, 1967) and it seemed appropriate to determine whether this output could be reduced by the administration of Trasylol.

\section{Materials and Methods}

Two patients with ulcerative colitis and two with polyposis coli entered hospital voluntarily for this study. Each had a well functioning ileostomy 
established for more than one year. The patients were put on a rigid diet containing a fixed daily amount of protein, fat, and carbohydrate. The ileostomy bags were emptied at least every six hours and the contents placed on ice until the 24-hour collection was complete. Four consecutive daily collections were made after which Trasylol in a dose of 500,000 units was administered intravenously over an eight-hour period in 2 pints of $0 \cdot 15 \mathrm{M} \mathrm{NaCl}$. Collections of ileal fluid were continued for a further two days after Trasylol was administered. Homogenates and supernatants were prepared from ileal fluid, and estimations made of their trypsin and chymotrypsin content as previously described (Roy et al, 1967).

\section{Results}

The output of trypsin and chymotrypsin in individual patients during the four-day control period was relatively constant for each patient although variations between patients were quite large. The highest daily output of an enzyme did not exceed the lowest by more than $35 \%$ in any one patient. The Figure is representative of the results obtained. The average daily output during the control period was calculated for each patient and compared with the average daily output during the 48-hour test period. Composite mean values for the group were calculated during each period (Table). No change in the output of trypsin or chymotrypsin was seen after Trasylol. It should be noted that only $63 \%$ of trypsin and $49 \%$ of chymotrypsin was present in the soluble supernatant in the pre-therapy samples, the remainder being associated with insoluble debris present in the homogenate. Trasylol did not affect this distribution.

\section{Discussion}

We were unable to demonstrate any change in the output of pancreatic enzymes from the terminal ileum of patients given Trasylol in a large dosage. We have given elsewhere our

\begin{tabular}{llllll}
\hline & \multicolumn{2}{l}{ Before Therapy } & & \multicolumn{2}{l}{ After Therapy } \\
\cline { 2 - 3 } \cline { 5 - 6 } & Homogenate $^{2}$ & Supernatant $^{2}$ & & Homogenate $^{2}$ & Supernatant \\
\hline Trypsin & $179 \pm 40$ & $113 \pm 20$ & & $184 \pm 43$ & $117 \pm 19$ \\
Chymotrypsin & $264 \pm 11$ & $129 \pm 20$ & & $256 \pm 25$ & $120 \pm 25$ \\
\hline
\end{tabular}

Table Effect of Trasylol on output of trypsin and chymotrypsin ${ }^{1}$

${ }^{1}$ Output (mg/day) for four patients is based on a single average daily reading for each patient during each period.

${ }^{2}$ Mean \pm SE.

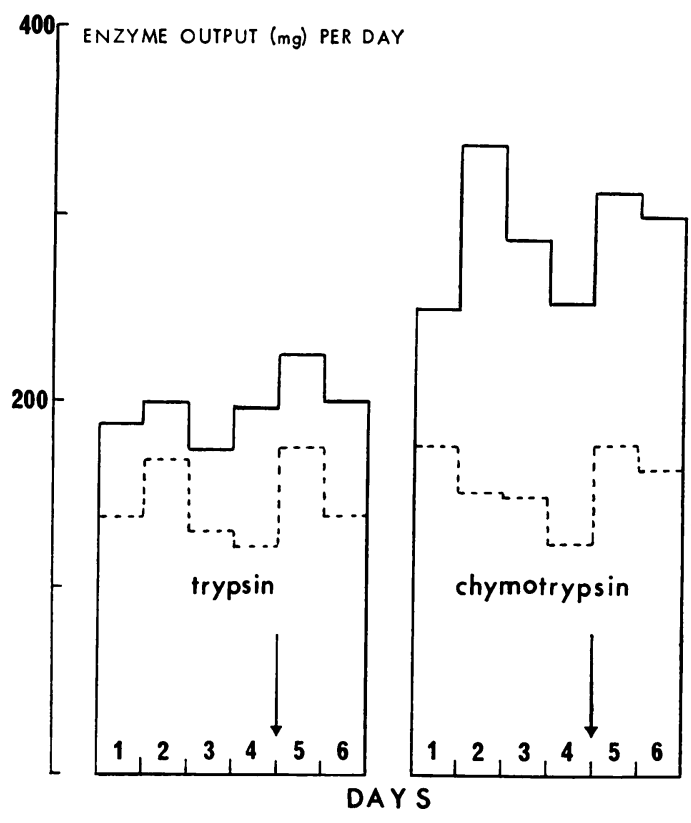

Fig. Daily output of trypsin and chymotrypsin from ileal stools of one patient. Trasylol administration (500,000 units intravenously) commenced at the end of the fourth day as indicated by arrow. The broken line indicates the output of soluble enzyme (supernatant), and the solid line the output of bound plus soluble enzyme (homogenate).

reasons for regarding this output as closely related to that of the pancreas (Roy et al, 1967; Goldberg, Campbell, and Roy, 1969) and consider the present findings indicative of a failure by Trasylol to diminish endogenous pancreatic enzyme secretion, in contrast to other workers who found a reduction in the output of enzymes when the gland was stimulated by exogenous pancreatic stimulants (Schultis and Rick, 1964). N These results also throw doubt on the biological N efficacy of the increased trypsin inhibitors in $N$ the pancreatic juice of patients given Trasylol $\mathrm{\omega}$ (Morgan et al, 1968). Other trypsin inhibitors are ineffective when the enzyme is protected by serum $\alpha_{2}$ macroglobulin (Haverback, Dyce, $\cong$ Bundy, Wirtschafter, and Edmondson, 1962; Bieth, Metais, and Warter, 1968). The presence of protective agents for trypsin in body fluids generally as well as in the pancreas, together with its secretion as a precursor which may be immune to the action of inhibitors, may partly explain why anti-trypsin therapy in acute pancreatitis has 8 not yet yielded the desired results. It is worth reiterating the statement by Haverback et al (1962) that such therapy is likely to be effective only if inhibition of bound trypsin occurs. 
We are grateful to Professor A. W. Kay for his encouragement of this work, and to Dr H. T. Howat for valuable discussion.

We also thank Dr D. Whitfield and Dr H. B. Allen, of FBA Pharmaceuticals Ltd, for their generous gift of Trasylol.

\section{References}

Bachrach, W. H., and Schild, P. D. (1968). A double-blind study of Trasylol in the treatment of pancreatitis. Ann. N.Y. Acad. Sci., 146, 580-592.

Baden, H., Jordal, K., Lund, F., and Zachariae, F. (1967). A double-blind controlled clinical trial of Trasylol. Preliminary results in acute pancreatitis and in prophylaxis against postoperative pancreatitis. Acta chir. scand., Suppl., 378, 97-100.

Bieth, J., Metais, P., and Warter, J. (1968). Activation, inhibition and protection of tryptic and $\alpha$-chymotryptic activity by normal human serum. Clin. chim. Acta, 20, 69-80.

Bundy, H. F., and Mehl, J. W. (1958). Trypsin inhibitors of human serum. I. Standardization, mechanism of reaction, and normal values. J. clin. Invest., 37, 947-955.

Dos Reis, L. (1967). Proteinase inhibitor and treatment of acute pancreatitis. An experimental study. Amer. Surg., 33, 311-316.

Gabryelewicz, A., Niewiarowski, S., Prokopowicz, J., and Chlebowski, J. (1969). Heparin and pretease inhibitors in the prevention of experimental acute pancreatic necrosis in dogs. Digestion, 2, 7-16.

Goldberg, D. M., Campbell, R., and Roy, A. D. (1969). Fate of trypsin and chymotrypsin in the human small intestine. Gut, 10, 477-483.

Groisser, V. W., Rauch, F., Floch, M., and Bobruff, J. (1966). Serum esterolytic activity in a wide variety of diseases. With special reference to pancreatic and liver disease. New Engl. J. Med., 274, 129-133.

Hansson, K., and Lenninger, S. (1967). Proteinase inhibitors in acute pancreatitis. Acta chir. scand. Suppl., 378, 103-109.

Haverback, B. J., Dyce, B., Bundy, H. F., Wirtschafter, S. K., and Edmondson, H. A. (1962). Protein binding of pancreatic proteolytic enzymes. $J$. clin. Invest., 41, 972-980.

Howat, H. T. (1969). Aprotinin ('Trasylol') in acute pancreatitis. Prescribers' J., 9, 82-84.
Kallos, J., Kahn, D., and Rizok, D. (1964). A new colorimetric method for serum trypsin determination. Canad. $J$. Biochem., 42, 235-241.

Keynes, W. M. (1967). Proteolytic enzyme inhibition in experimental pancreatitis. In Proteinase Inhibition in Medicine and Surgery, pp. 42-43. FBA Pharmaceuticals, London.

Kneisel, J. J. (1968). A clinical trial of an enzyme inhibitor in pancreatitis. Arch. Surg., 96, 442-449.

Kune, G. A. (1968). The treatment of experimentally induced acute pancreatitis. Aust. N.Z. J. Surg., 38, 150-153.

McCutcheon, A. D., and Race, D. (1963). Experimental pancreatitis: use of a new antiproteolytic substance, Trasylol. Ann. Surg., 158, 233-239.

Morgan, A., Robinson, L. A., and White, T. T. (1968). Postoperative changes in the trypsin inhibitor activities of human pancreatic juice and the influence of infusion of Trasylol on the inhibitor activity. Amer. J. Surg., 115, 131-139.

Nardi, G. L. (1963). Current concepts in therapy. Pancreatitis. New Engl. J. Med., 268, $1065-1067$.

Nemir, P. J., Hoferichter, J., and Drabkin, D. L. (1963). The protective effect of proteinase inhibitor in acute necrotizing pancreatitis. An experimental study. Ann. Surg., 158, 655665.

Nodine, J. H., and Greberman, M. (1968). Proteinase inhibitors in human pancreatitis: digital computer analysis of clinical research data. Ann. N.Y. Acad. Sci., 146, 564-579.

Roy, A. D., Campbell, R., and Goldberg, D. M. (1967). Effect of diet on the trypsin and chymotrypsin output in the stools of patients with an ileostomy. Gastroenterology, 53, 584589.

Schultis, K., and Rick, W. (1964). Zur Beeinflussung der Pankreasfunktion beim Menschen durch Proteaseninhibitoren. Verh. dtsch. Ges. Inn. Med., 70, 824-828.

Siegelman, A. M., Carlson, A. S., and Robertson, T. (1962). Investigation of serum trypsin and related substances. 1 . The quantitative demonstration of trypsin-like activity in human blood serum by a micromethod. Arch. Biochent. 97, 159-163.

Skinner, D. B., Corson, J. G., and Nardi, G. L. (1968). Aprotinin therapy as prophylaxis against post-operative pancreatitis in humans. A controlled evaluation. J. Amer. med. Ass., 204, 945-948.

Skyring, A., Singer, A., and Tornya, P. (1965). Treatment of acute pancreatitis with Trasylol: report of a controlled therapeutic trial. Brit. med. J., 2, 627-629.

Trapnell, J. E., Talbot, C. H., and Capper, W. M. (1967). Trasylol in acute pancreatitis. Amer. J. dig. Dis., 12, 409-412. 